\title{
Effect of lead on erythrocyte membranes
}

\author{
K FUKUMOTO, I KARAI, AND S HORIGUCHI \\ From the Department of Preventive Medicine and Public Health, Osaka City University Medical School, \\ Osaka, 545 Japan
}

ABSTRACT The effect of blood lead on erythrocyte membrane proteins was studied in 28 workers from a scrap lead refining factory and in 18 controls working in railway construction. Sodium dodecyl sulphate-polyacrylamide gel electrophoresis (SDS-PAGE) of the polypeptides in the erythrocyte membrane showed that bands 3 and $4 \cdot 1$ had significantly decreased while bands $2 \cdot 3$, 6 , and 7 had significantly increased in the lead workers compared with the controls. For the lead workers, the correlation coefficients between blood lead and bands 2.3 and 3 were $r=0.545$ ( $p<$ $0.01)$ and $r=-0.51(p<0.01)$ respectively. These results suggest that the decrease in erythrocyte membrane permeability results from a decrease in the membrane transfer protein responsible for band 3 .

Several studies have been conducted on the effects of lead on erythrocyte membrane. Thus Barltrop and Smith ${ }^{1}$ reported that lead combined with the $\beta$-chain component of haemoglobin, Mortensen and Kellog ${ }^{2}$ showed that lead combined with the erythrocyte membrane, and Rubino et $a^{3}$ reported that the lifespan of erythrocytes had been reduced by lead toxicosis. Selhi and White ${ }^{4}$ have found both erythrocyte membrane damage and membrane protein conformation changes. Ong and $\mathrm{Lee}^{\mathrm{s}}$ studied the in vitro distribution of lead in peripheral blood and reported that $14.1 \%$ of ${ }^{203} \mathrm{~Pb}$ combined with erythrocyte membrane protein. Others suggested that lead attached to membrane proteins is responsible for the decreased lifespan of erythrocytes. ${ }^{67}$ The effects, however, of lead on the proteins of the erythrocyte membrane have not been clearly shown. In the present work we used electrophoresis to study membrane proteins in lead workers.

\section{Materials and methods}

\section{SUBJECTS}

Twenty eight male workers exposed to lead in a lead refining factory were studied. Their mean age was $46 \cdot 8$ (range 30-70). Eighteen men employed in railway construction served as controls. Their mean age was $46 \cdot 0$ (range 28-65). Both groups completed

Requests for reprints to: Dr K Fukumoto.

Received 2 February 1982

Accepted 1 September 1982 a health questionnaire and clinical laboratory tests were performed before the experiment; workers with abnormal liver function test results and endocrinological disorders were excluded. Heparinised blood was taken and placed immediately in iced water.

PREPARATION OF ERYTHROCYTE MEMBRANE The method of Dodge $e t a^{8}$ was used. The membrane was prepared and stored at below $4^{\circ} \mathrm{C}$.

\section{ELECTROPHORESIS (SDS-PAGE)}

The method of Fairbanks et al $^{9}$ was used. Reagents were of the highest purity available commercially, and purified water was used. Five percent of SDS gel was used.

ANALYSIS OF ELECTROPHOROGRAMS

A densitometer (Jyoko Co Ltd, Japan) for serum protein electrophoresis was modified and membrane protein fractions were measured at $570 \mathrm{~nm}$. The bands of the densitometric scan were numbered according to Fairbanks et $a l^{9}$ from the cathode side.

ASSAY OF ERYTHROCYTE MEMBRANE PROTEIN The method of Lowry et al ${ }^{10}$ was used.

DETERMINATION OF BLOOD AND URINE LEAD Samples were dried and ashed then measured by dithizon-polarography. ${ }^{11}$

URINE $\delta$-AMINOLAEVULINIC ACID

The method of Tomokuni and Ogata ${ }^{12}$ was used. 
Table 1 Lead exposure levels for lead workers and controls

\begin{tabular}{|c|c|c|c|c|}
\hline & \multicolumn{2}{|c|}{$\begin{array}{l}\text { Lead workers } \\
(n=28)\end{array}$} & \multicolumn{2}{|l|}{$\begin{array}{l}\text { Controls } \\
(n=18)\end{array}$} \\
\hline & $G M$ & $\begin{array}{l}\text { Log transformation } \\
\text { Mean } \pm S D\end{array}$ & $G M$ & $\begin{array}{l}\text { Log transformation } \\
\text { Mean } \pm S D\end{array}$ \\
\hline $\begin{array}{l}\text { Blood lead }(\mu \mathrm{g} / 100 \mathrm{~g}) \\
\text { Urine lead }(\mu \mathrm{g} / 1) \\
\text { Urine } \delta \text {-ALA }(\mu \mathrm{g} / \mathrm{l})\end{array}$ & $\begin{array}{r}35 \cdot 97^{* * *} \\
103 \cdot 36^{* * *} \\
7134^{* * *}\end{array}$ & $\begin{array}{l}1.56 \pm 0.146 \\
2.01 \pm 0.378 \\
3.85 \pm 0.520\end{array}$ & $\begin{array}{r}5 \cdot 23 \\
12 \cdot 41 \\
2250\end{array}$ & $\begin{array}{l}0.72 \pm 0.083 \\
1 \cdot 09 \pm 0.243 \\
3 \cdot 35 \pm 0.134\end{array}$ \\
\hline
\end{tabular}

$\mathrm{GM}=$ Geometric mean; ALA $=$ Aminolaevulinic acid.

${ }^{* * *} \mathrm{p}<0.001$.

Table 2 Mean percentage of each band in electrophorograms of erythrocyte membrane and their lead worker and control ratio

\begin{tabular}{|c|c|c|c|}
\hline Band No & $\begin{array}{l}\text { Lead workers } \\
(n=28) \\
\text { Mean } \pm S D\end{array}$ & $\begin{array}{l}\text { Controls } \\
(n=18) \\
\text { Mean } \pm S D\end{array}$ & $\begin{array}{l}\text { Lead workers } \\
\text { controls }\end{array}$ \\
\hline $\begin{array}{l}1 \\
2 \\
2 \cdot 1 \\
2 \cdot 2 \\
2 \cdot 3 \\
3 \\
4 \cdot 1 \\
4 \cdot 2 \\
4 \cdot 5 \\
5 \\
6 \\
7\end{array}$ & $\begin{array}{c}10.23 \pm 0.813 \\
11.84 \pm 0.851 \\
6.93 \pm 0.814 \\
4.89 \pm 0.581 \\
6.54 \pm 0.630^{* * *} \\
9.23 \pm 0.610^{* * *} \\
9.73 \pm 0.368^{*} \\
8.86 \pm 0.371 \\
9.60 \pm 0.550 \\
9.73 \pm 0.479 \\
6.89 \pm 0.510^{*} \\
6.03 \pm 0.820^{*}\end{array}$ & $\begin{array}{r}10.52 \pm 0.817 \\
12.19 \pm 0.944 \\
6.36 \pm(0.792 \\
4.90 \pm(0.599 \\
5.87 \pm(0.643 \\
10.11 \pm 0.636 \\
10.00 \pm 0.425 \\
8.93 \pm(0.471 \\
9.46 \pm 0.564 \\
9.68 \pm 0.417 \\
6.51 \pm 0.515 \\
5.46 \pm 0.739\end{array}$ & $\begin{array}{l}0.972 \\
0.971 \\
1.005 \\
() \cdot 998 \\
1 \cdot 114 \\
0.913 \\
0.973 \\
0.992 \\
1 \cdot 015 \\
1 \cdot() 05 \\
1 \cdot 058 \\
1 \cdot 1(04\end{array}$ \\
\hline
\end{tabular}

${ }^{*} \mathrm{p}<0.05 ;{ }^{* * *} \mathrm{p}<0.001$

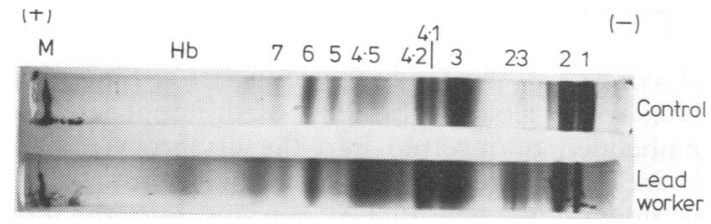

Fig 1 SDS-PAGE disc of control and lead exposed workers. Fractionation of erythrocyte membrane protein from control (blood lead, $7.3 \mu \mathrm{g} / 100 \mathrm{~g}$ ) and lead exposed worker (blood lead, $56 \cdot 8 \mu \mathrm{g} / 100 \mathrm{~g}$ ). Bands were numbered from cathode. $M=$ Marker.

\section{Results}

All the three parameters of lead exposure were significantly higher (see table 1) in lead workers than in controls. Table 2 shows the results of SDSPAGE analysis of membrane proteins. The mean percentage of each band fraction in electrophorograms and their lead workers to controls ratio were calculated.

Lead increased bands $2 \cdot 3,6$, and 7 , and decreased bands 3 and $4 \cdot 1$. Figure 1 compares the results of SDS-PAGE analysis of a lead worker whose blood lead concentration was $56 \cdot 8 \mu \mathrm{g} / 100 \mathrm{~g}$ with the
Table 3 Correlation coefficients between the relative size of bands and blood lead

\begin{tabular}{lc}
\hline Band No & $r$ \\
\hline $2 \cdot 3$ & $0 \cdot 55^{* *}$ \\
3 & $-0 \cdot 51^{* *}$ \\
$4 \cdot 1$ & $-0 \cdot 31$ \\
6 & $0 \cdot 30$ \\
7 & $0 \cdot 11$ \\
\hline$* * \mathrm{p}<0.01$ &
\end{tabular}

Table 4 The molecular weights of polypeptides in the erythrocyte membrane of lead workers

\begin{tabular}{ll}
\hline Band No & $\begin{array}{l}\text { Molecular weight (daltons) } \\
\text { Mean } \pm S D\end{array}$ \\
\hline 2 & $220700 \pm 3600$ \\
$2 \cdot 3$ & $133800 \pm 3100$ \\
3 & $93400 \pm 2000$ \\
\hline
\end{tabular}

Each result is the average of ten measurements.

analysis of a control with $7 \cdot 3 \mu \mathrm{g} / 100 \mathrm{~g}$ blood lead concentration. In the lead worker band 2.3 was much larger than that in the control. Figure 2 shows the densitometric scans of their blood. Band 3 were smaller in band $2 \cdot 3$, larger in the lead worker. No 


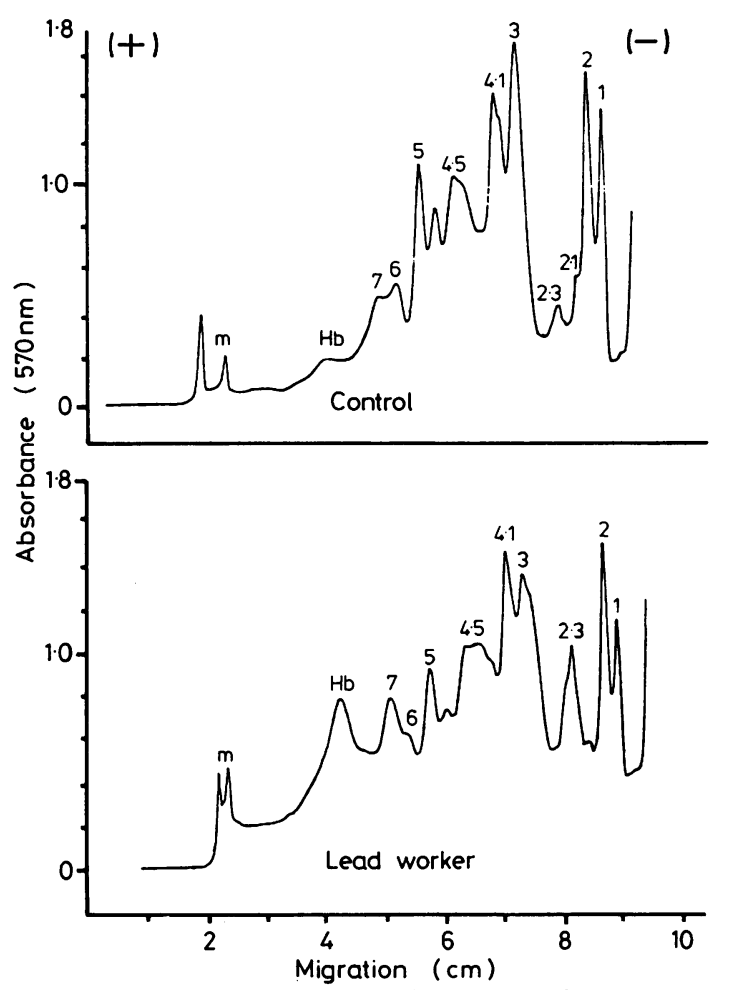

Fig 2 Electrophorogram of erythrocyte membrane proteins of control and lead exposed worker. $M=$ Marker, $\mathrm{H} b=$ haemoglobin.

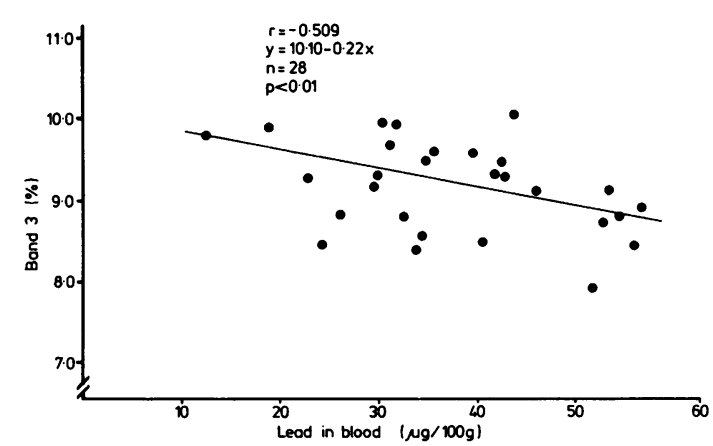

Fig 3 Correlation between blood lead and band 3 erythrocyte membrane protein in lead exposed group.

other condition has been reported which can increase band $2 \cdot 3$.

Table 3 shows the correlation between the bands that gave significant differences between lead workers and controls by PAGE analysis and blood lead. The coefficients of correlation between bands 2.3 or 3 and blood lead were $r=0.55(p<0.01)$ and $r=$

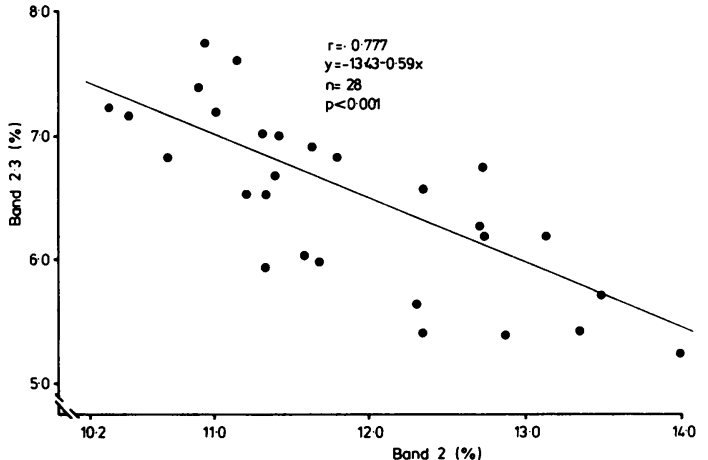

Fig 4 Correlation between band 2 and band $2 \cdot 3$ in lead exposed group.

$-0.51(p<0.01)$ respectively. For band 3 see also fig 3 . Bands $4 \cdot 1,6$, and 7 gave very low correlation coefficients with blood lead. Table 4 shows the molecular weights of the polypeptides in bands 2 , $2 \cdot 3$ and 3 .

As shown in figure 4 , significant correlation was observed between bands 2 and $2 \cdot 3(r=-0.78, p<$ $0 \cdot 001$ ) while other bands showed no significant relationship. Reproducibility of each band was studied. Precision $(n=10)$ of each band corresponded to $\mathrm{CV}$ of $1 \cdot 63-2 \cdot 31 \%$ (mean 1.98 ).

\section{Discussion}

According to the fluid mosaic model of Singer and Nicolson, ${ }^{13}$ globular proteins of different sizes are embedded or inserted into the erythrocyte membrane. There are two kinds of globular proteins, one is integral protein that penetrates into the lipid bilayer and corresponds to band 3. It has roles in membrane transport such as ion selectivity and water transport. Another type is peripheral protein, which is composed of many bands such as spectrin, band 1 , and band 2 . They exist on the inside surface of the cell membrane and maintain the fluidity of membrane construction. ${ }^{14} 15$

Our results showed that band 3 decreased in lead workers in table 2 and fig 3 . Band 3 is a membrane transfer protein. ${ }^{16}{ }^{17}$ Its decrease lowers the ability of membrane transportation resulting in difficulty in the preservation of $\mathrm{Na}^{+}$and water and therefore a decrease in erythrocyte volume. ${ }^{18}$

Band 2.3 was increased in lead workers and showed a highly negative correlation with band 2 (fig 4). As the molecular weights of band 2 (spectrin) and band 2.3 were 220700 and 133800 , respectively (table 4 ), band 2.3 seems to be a cleavage product of band 2 -that is, the light chain of the polypeptide. Ong and $\mathrm{Lee}^{\mathrm{s}}$ recently found that 
polypeptide combined with lead in the erythrocyte membrane have molecular weights of from 130000 to 230000 - that is in the range of our bands 2 and 2.3.

\section{References}

' Bartrop D, Smith A. Lead binding to human haemoglobin. Experientia 1972;28:76-7.

${ }^{2}$ Mortensen RA, Kellog KE. The uptake of lead by blood cells as measured with a radioactive isotope. J Cell Physiol 1944;23:11-6.

${ }^{3}$ Rubino GF, Prano V, Fiorina L. Cited by Griggs. ${ }^{\circ}$ Folia Med (Napoli) 1964;39:1117.

4 Selhi HS, White JM. The effect of lead on the red cell membrane. Postgrad Med J 1975;51:765-9.

${ }^{5}$ Ong CN, Lee WR. Distribution of lead-203 in human peripheral blood in vitro. Br J Ind Med 1980;37:78-84.

- Griggs RC. Lead poisoning: hematologic aspect. Prog Hematol 1964;4:117-37.

${ }^{7}$ Berg PD, Tschudy DP, Shepley LA, Wanger LG, Berlin NI. Hematologic and biochemical studies in a case of lead poisoning. Am J Med 1970;48:137-44.

8 Dodge JT, Mitchell C, Hanahan DJ. The preparation and chemical characteristic of hemoglobin-free ghost of human erythrocytes. Arch Biochem Biophys 1963;110:119-30.
9 Fairbanks G, Steck TL, Wallch DFH. Electrophoretic analysis of the major polypeptide of the human erythrocyte membrane. Biochem 1971;10:2606-17.

${ }^{10}$ Lowry OH, Rosenbrough NJ, Farr AL, Randall RJ. Protein measurement with the folin phenol reagent. J Biol Chem 1951;193:265-75.

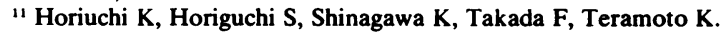
A polarographic method for the determination of a small amount of lead in biological materials. Osaka City Med J 1968;14:113-8.

${ }^{12}$ Tomokuni K, Ogata M. Simple method for determination of urinary $\delta$-aminolevulinic acid as index of lead exposure. Clin Chem 1972;18:1534-6.

${ }^{13}$ Singer SJ, Nicolson GL. The fluid mosaic model of the structure of cell membrane. Science 1972;175:720-31.

${ }^{14}$ Steck $L$. The organization of proteins in the human red blood cell membrane. J Cell Biol 1974;62:1-19.

is Lux SE. Spectrin-actin membrane skeleton of normal and abnormal red blood cells. Semin Hematol 1979;16:21-51.

${ }^{16}$ Brown PA, Feinstein MB, Sháafi RI. Membrane proteins related to water transport in human erythrocytes. Nature 1975; 254:523-5.

${ }^{17}$ Cabantchik ZI, Rothstein A. Membrane protein related anion permeability of human red blood cells. J Memb Biol 1974;15:207-26.

18 Karai I, Fukumoto K, Horiguchi S. The effect of lead on intracellular water content of human red blood cells. Jpn J Ind Health 1981;23:305-7. 